\title{
Analisis Komparatif Kinerja Keuangan Perbankan Syariah dan Perbankan Konvensional
}

\author{
Farizal Julian Aski ${ }^{1}$ \\ Fakultas Ekonomi dan Bisnis \\ Universitas Udayana, Indonesia
}

\author{
I Gusti Ngurah Agung Suaryana ${ }^{2}$ \\ Fakultas Ekonomi dan Bisnis \\ Universitas Udayana, Indonesia
}

ABSTRAK

Tujuan dari penelitian ini adalah menganalisis: 1) Perbedaan kinerja perbankan syariah dan perbankan konvensional. 2) Bagaimana kinerja perbankan syariah dan perbankan konvensional. Penelitian ini dilakukan pada perusahaan perbankan yang terdaftar di Bank Indonesian (BI) selama periode sembilan tahun, yaitu tahun 2008-2016. Teknik pengambilan sampe menggunakan teknik purposive sampling. Jumlah sampel yang diperoleh sebanyak perusahaan dengan jumlah 69 pengamatan. Pengumpulan data menggunakan metode observasi non partisipan. Teknik analisis yang digunakan adalah analisis komparatif mann-whitney test. Hasil penelitian ini yaitu: 1) Berdasarkan semua rasio yang menjadi proksi (CAR, NPL, BOPO, ROA, dan LDR), ada perbedaan yang signifikan pada kinerja perbankan syariah dan perbankan konvensional. 2) Ternyata selama tahun 2008-2016 kinerja perbankan syariah tidak lebih baik dari perbankan konvensional.

Kata Kunci: Perbankan Syariah; Perbankan Konvensional; Analisis Komparatif.

\section{Comparative Analysis of Islamic Banking and Conventional Banking Financial Performance}

\section{ABSTRACT}

The purpose of this study is to analyze: 1) Differences in the performance of Islamic banking and conventional banking. 2) How is the performance of Islamic banking and conventional banking. This research was conducted at banking companies registered with Bank Indonesia (BI) for a period of nine years, namely 2008-2016. The sampling technique used was purposive sampling technique. The number of samples obtained as many as companies with a total of 69 observations. Collecting data using non-participant observation methods. The analysis technique used is the comparative analysis Mann-Whitney test. The results of this study are: 1) Based on all the ratios that become proxies (CAR, NPL, OEOI, ROA, and LDR), there are significant differences in the performance of Islamic banking and conventional banking. 2) It turns out that during 2008-2016 the performance of Islamic banking was no better than conventional banking.

Keywords: $\quad$ Syariah Banking; Conventional Banking; Comparative Analysis.

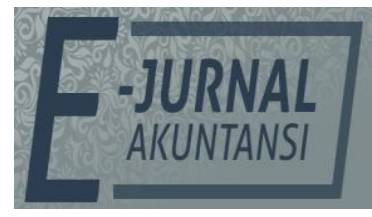

e-ISSN 2302-8556

Vol. 31 No. 5

Denpasar, Mei 2021

Hal. 1125-1140

DOI:

10.24843/EJA.2021.v31.i05.p05

PENGUTIPAN:

Aski. F.J., \& Suaryana, I

G.N.A. (2021). Analisis

Komparatif Kinerja

Keuangan Perbankan

Syariah dan Perbankan

Konvensional. E-Jurnal Akuntansi, 31(5), 1125-1140

RIWAYAT ARTIKEL:

Artikel Masuk:

18 Januari 2018

Artikel Diterima:

8 Agustus 2018

Artikel dapat diakses : https://ojs.unud.ac.id/index.php/Akuntansi/index 


\section{PENDAHULUAN}

Tahun 2008 adalah tahun yang menjadi momok bagi perekonomian seluruh Negara di dunia. Pasalnya tahun ini krisis perekonomian menjalar ke seluruh wilayah di belahan dunia. Banyak negara mengalami pertumbuhan ekonomi yang negatif tetapi ada pula yang tetap menikmati pertumbuhan positif, contohnya China, India, dan Indonesia. Efeknya masih terasa hingga sekarang. Amerika Serikat telah lebih dulu keluar dari jurang resesi ekonomi tapi kawasan Eropa hingga kini masih berkutat dengan krisis utang mereka dan belum mampu keluar dari krisis tersebut.

Semenjak tahun 2008 hingga 2016, banyak peristiwa yang mewarnai geliat ekonomi di seluruh belahan dunia yang menyusul setelah krisis tahun 2008. Dari perlambatan ekonomi China dan emerging market, krisis eropa, Brexit, ketidakpastian suku bunga The FED, terorisme dan imigran, memanasnya konflik di beberapa wilayah, hingga terpilihnya Donal Trump. Peristiwaperistiwa tersebut dapat mempengaruhi kestabilan ekonomi global baik langsung atau pun tidak langsung dan mengarah kepada krisis global jilid selanjutnya jika tidak di atasi.

Salah satu sektor yang berperan vital bagi pertumbuhan ekonomi suatu Negara adalah sektor perbankan. Bank dikenal sebagai lembaga keuangan yang kegiatan utamanya menerima simpanan giro, tabungan, dan deposito. Kemudian bank juga dikenal sebagai tempat untuk meminjam uang atau kredit bagi masyarakat yang membutuhkannya. Disamping itu, bank juga dikenal sebagai tempat untuk menukar uang, atau menerima segala macam bentuk pembayaran dan setoran (Kasmir, 2002:23).

Di Indonesia terdapat dua jenis bank yang melakukan aktivitas dalam lingkup yang berbeda, yaitu bank konvensional dengan konsep bunga dan bank syariah dengan konsep bagi hasil. Bank yang berdasarkan pada prinsip syariah tidak mengenal bunga dalam memberikan jasa simpanan maupun pinjaman. Di bank ini jasa yang diberikan disesuaikan dengan hukum Islam.

Perbedaan sistem perbankan syariah dan konvensional terletak pada distribusi resiko usaha. Pada sistem bunga, balas jasa modal ditentukan berdasarkan persentase tertentu dan resiko sepenuhnya ditanggung oleh salah satu pihak. Untuk hal nasabah sebagai deposan, resiko sepenuhnya berada pada pihak bank, sebaliknya apabila nasabah sebagai peminjam, resiko sepenuhnya berada ditangan peminjam. Sedangkan pada sistem syariah diterapkan sistem bagi hasil dimana jasa atas modal diperhitungkan berdasarkan keuntungan atau kerugian yang diperoleh yang didasarkan pada akad. Prinsip utama dari akad adalah keadilan antara pemberi modal dan pemakai modal. Prinsip ini berlaku baik bagi debitur maupun kreditur.

Pola bagi hasil ini memungkinkan nasabah untuk mengawasi langsung kinerja bank syariah melalui monitoring atas jumlah bagi hasil yang diperoleh. Jika jumlah keuntungan bank semakin besar maka semakin besar pula bagi hasil yang diterima nasabah, demikian sebaliknya. Jumlah bagi hasil yang kecil atau mengecil dalam waktu cukup lama menjadi indikator bahwa pengelolaan bank merosot. Keadaan itu merupakan peringatan dini yang transparan dan mudah bagi nasabah. Berbeda dari perbankan konvensional, nasabah perbankan syariah tidak dapat menilai kinerja hanya dari indikator bunga yang diperoleh. 
Sebagai salah satu lembaga keuangan, bank perlu menjaga kinerjanya agar dapat beroperasi secara optimal. Terlebih lagi bank syariah harus bersaing dengan bank konvensional yang dominan dan telah berkembang pesat di Indonesia. Persaingan yang semakin tajam ini harus dibarengi dengan manajemen yang baik untuk bisa bertahan di industri perbankan dan juga saat krisis melanda. Salah satu faktor yang harus diperhatikan oleh bank untuk bisa terus bartahan hidup adalah kinerja (kondisi keuangan) bank yang sehat.

Menurut Indra Prasetyo (2008), dalam penilaian kinerja keuangan perusahaan, stakeholder akan sangat terbantu dengan laporan keuangan yang diterbitkan oleh perusahaan tersebut. Hal yang dapat diperoleh dari laporan keuangan adalah: (1) sebagai alat pembanding kinerja suatu perusahaan dengan perusahaan lain dalam industri yang sama; (2) sebagai alat evaluasi untuk menunjukkan posisi keuangan perusahaan.

Berdasarkan laporan keuangan akan dapat dihitung sejumlah rasio keuangan yang lazim dijadikan dasar penilaian tingkat kesehatan bank. Analisis rasio keuangan memungkinkan manajemen untuk mengidentifikasikan perubahan-perubahan pokok pada trend jumlah, dan hubungan serta alasan perubahan tersebut. Hasil analisis laporan keuangan akan membantu mengintepretasikan berbagai hubungan serta kecenderungan yang dapat memberikan dasar pertimbangan mengenai potensi keberhasilan perusahaan dimasa mendatang. Untuk menilai kinerja perusahaan perbankan umumnya digunakan aspek penilaian, yaitu: Capital, Assets, Management, Earnings, dan Liquidity yang biasa disebut CAMEL. Aspek-aspek tersebut menggunakan rasio keuangan.Hal ini menunjukan bahwa rasio keuangan dapat digunakan untuk menilai tingkat kesehatan bank. CAMEL tidak sekedar mengukur tingkat kesehatan bank, tetapi juga digunakan sebagai indikator dalam menyusun peringkat dan memprediksi kebangkrutan bank (Payamata \& Machfoedz, 1999:56). Berdasarkan latar belakang yang telah dipaparkan, penulis tertarik untuk melakukan penelitian dengan judul "Analisis Komparatif Kinerja Keuangan Perbankan Syariah dan Perbankan Konvensional"

Berdasarkan pada uraian yang telah dikemukakan pada latar belakang maka dapat dirumuskan permasalahan sebagai berikut, 1) Bagaimana kinerja keuangan perbankan syariah jika dibandingkan dengan perbankan konvensional untuk masing-masing rasio keuangan?; 2) Apakah terjadi perbedaan yang signifikan atas kinerja keuangan perbankan syariah jika dibandingkan dengan perbankan konvensional secara keseluruhan?

Sesuai dengan pokok permasalahan yang telah dikemukakan maka tujuan penelitian ini adalah: 1) Untuk mengetahui seberapa besar kinerja keuangan perbankan syariah jika di bandingkan dengan kinerja keuangan perbankan konvensional; 2) Untuk mengetahui perbedaan kinerja keuangan perbankan syariah dibandingkan kinerja keuangan perbankan konvensional.

Adapun kegunaan yang diharapkan dari penelitian ini adalah: 1) kegunaan teoritis, penelitian ini diharapkan dapat memberikan kontribusi pada pengembangan ilmu ekonomi khususnya ilmu ekonomi syariah dan perbankan syariah dan sebagai bahan studi atau literatur tambahan terhadap penelitian yang sudah ada sebelumnya. 2) kegunaan praktis, penelitian ini diharapkan dapat memberikan kontribusi yang bermanfaat sebagai bahan studi dan literatur 
bagi mahasiswa/mahasiswi ataupun peneliti yang ingin melakukan penelitian sejenis selanjutnya.

Teori fundamental adalah teori yang didasarkan pada fundamental ekonomi suatu perusahaan. Teori ini menitik beratkan pada rasio finansial dan kejadian-kejadian yang secara langsung maupun tidak langsung mempengaruhi kinerja keuangan perusahaan. Teori ini didasarkan pada situasi dan kondisi ekonomi, politik dan keamanansecara global. Informasi maupun berita-berita yang berhubungan baik secaralangsung dengan situasi perekonomian dapat digunakan sebagai indikator yangcukup penting. Sebagian pakar berpendapat teori fundamental lebih cocok untukmembuat keputusan dalam memilih saham perusahaan mana yang dibeli untukjangka panjang.

Dalam industri perbankan, alat analisis yang digunakan untuk menilai kinerja sebuah bank dengan menggunakan proksi rasio keuangan, yaitu himpunan indikator yang berunsurkan variabel-variabel Capital, Assets Quality, Management, Eearning dan Liquidity. Proksi rasio keuangan tidak sekedar mengukur tingkat kesehatan sebuah bank, tapi sering pula sebagai indikator dalam menyusun peringkat dan memprediksi kebangkrutan bank.

Kekurangan modal merupakan gejala umum yang dialami bank-bank di negara-negara berkembang. Kekurangan modal tersebut dapat bersumber dari dua hal, yang pertama adalah karena modal yang jumlahnya kecil, yang kedua adalah kualitas modalnya yang buruk. Dengan demikian, pengawas bank harus yakin bahwa bank harus mempunyai modal yang cukup, baik jumlah maupun kualitasnya. Selain itu, para pemegang saham maupun pengurus bank harus benar-benar bertanggung jawab atas modal yang sudah ditanamkan.

Umar Hamdan \& Andi Wijaya (2006) melakukan penelitian untuk mengetahui dan menganalisis tingkat resiko bisnis BPR Konvensional dan BPR Syariah. Analisis yang digunakan adalah analisis diskriminan (Z-score). Sedangkan untuk rasio yang digunakan adalah rasio likuditas (Asset to LoanRatio, Cash Ratio, LDR), rasio solvabilitas (Capital Ratio, Capital Risk, Capital Adequency Ratio), dan rasio rentabilitas (Gross Profit Margin, Net Profit Margin, Return on Equity Capital). Sampel BPR, yaitu satu BPR Konvensional dan satu BPR Syariah. Hasil penelitian tersebut kinerja rasio CAR pada bank syariahberbeda dan lebih baik dari pada bank konvensional. Berdasarkan uraian tersebut, dapat diajukan hipotesis alternatif sebagai berikut.

$\mathrm{H}_{1}$ : Capital adequacy Ratio (CAR) perbankan syariah dan bank konvensional berbeda.

NPL atau Non Performing Loan adalah salah satu tolak ukur kesehatan bank dari sisikualitas aset. NPL atau Non Performing Loan, adalah besarnya jumlah kredit bermasalah pada suatu Bank dibanding dengan total keseluruhan kreditnya. Non Performing Loan (NPL) juga merupakan rasio keuangan yang bekaitan dengan risiko kredit. Risiko kredit adalah risiko dari kemungkinan terjadinya kerugian bank sebagai akibat dari tidak dilunasinya kembali kredit yang diberikan bank kepada debitur. Meningkatnya Non Performing Loan (NPL) akan mengurangi jumlah modal bank. Selain itu meningkatnya NPL akan mempengaruhi bank dalam menyalurkan kredit pada periode berikutnya. Kondisi seperti ini akan mengurangi perkembangan deviden dan laba ditahan atau modal bank tersebut. 
Bank dikatakan mempunyai NPL yang tinggi jika banyaknya kredit yang bermasalah lebih besar daripada jumlah kredit yang diberikan kepada debitur. Apabila suatu bank mempunyai NPL yang tinggi, maka akan memperbesar biaya, baik biaya pencadangan aktiva produktif maupun biaya. Sehingga semakin tinggi rasio ini maka akan semakin buruk kualitas kredit bank yang menyebabkan jumlah kredit bermasalah semakin besar, maka kemungkinan suatu bank dalam kondisi bermasalah semakin besar.

Anggraini (2012) meneliti topik mengenai perbandingan kinerja perbankan syariah dengan perbankan konvensionaldengan menggunakan uji IndependentSample T-Test untuk membandingkan kinerja dua jenis perbankan tersebut.Penelitian ini dilakukan pada PT. Bank Syariah Mandiri dan PT. Bank Muamalat Indonesia (mewakili bank syariah), PT. Bank Negara Indonesia, PT. Bank Mandiri, PT. Bank Rakyat Indonesia, dan PT. Bank Tabungan Negara (mewakili bank konvensional). Aspek yang dianalisis dalam penelitian ini ada lima dimana aspek permodalan menggunakan rasio CAR (Capital Adequacy Ratio), aspek kualitas aktiva produktif menggunakan rasio NPL (Non Performing Loan), aspek rentabilitas menggunakan rasio ROA (Return On Assets), aspek efisiensi menggunakan rasio BOPO (Beban Operasional terhadap Pendapatan Operasional), dan aspek likuiditasmenggunakan rasio LDR (Loan to Deposit Ratio). Berdasarkan hasil penelitan yang telah dilakukan pada beberapa bank yang menjadi sampel dari perbankan syariah dan perbankan konvensional, analisis kinerja keuangan yang diperoleh dari rasio NPL menunjukkan bahwa terdapat perbedaan yang signifikan antara kinerja perbankan syariah dibandingkan dengan perbankan konvensional. Berdasarkan uraian tersebut, dapat diajukan hipotesis alternative sebagai berikut.

$\mathrm{H}_{2}$ : Non Performing Loan (NPL) bank syariah dan bank konvensional berbeda.

Manajemen atau pengelolaan suatu bank akan menentukan sehat tidaknya suatu bank. Mengingat hal tersebut, maka pengelolaan suatu manajemen sebuah bank mendapatkan perhatian yang besar dalam penilaian tingkat kesehatan suatu bank dan diharapkan dapat menciptakan dan memelihara kesehatannya.

Penilaian faktor manajemen dalam penilaian tingkat kesehatan bank umum dilakukan dengan melakukan evaluasi terhadap pengelolaan terhadap bank yang bersangkutan dengan rasio BOPO. Rasio ini digunakan untuk mengetahui tingkat perbandingan antara biaya operasional yang ditanggung bank apabila dibandingkan dengan pendapatan operasional yang mampu dihasilkan. Rasio ini diharapkan kecil karena biaya yang terjadi diharapkan dapat tertutupi dengan pendapatan operasional yang dihasilkan pihak bank.

Widya Wahyu Ningsih (2012) meneliti perbandingan kinerja keuangan Bank Umum Syariah dengan Bank Umum Konvensional di Indonesia pada periode 2006-2010 dengan menggunakan rasio keuangan CAR, LDR, NPL, BOPO, dan ROA. Sampel yang digunakan sebanyak 4 sampel, 2 Bank Umum Syariah (Bank Syariah Mandiri dan Bank Mega Syariah), dan 2 Bank Umum Konvensional (Bank Mandiri dan Bank Mega).Teknik analisis yang digunakan untuk melihat perbandingan kinerja keuangan Bank Umum Syariah dengan Bank Umum Konvensional adalah metode Independent sample t-test.Analisis yang dilakukan menunjukkan bahwa terdapat perbedaan yang signifikan untuk rasio 
keuangan BOPO antara Bank Umum Syariah dengan Bank Umum Konvensional di Indonesia atas uraian tersebut, dapat diajukan hipotesis berikut.

$\mathrm{H}_{3}$ : Beban operasional pada pendapatan operasional (BOPO)bank syariah dan bank konvensional berbeda.

Salah satu parameter untuk mengukur tingkat kesehatan suatu bank adalah kemampuan bank untuk memperoleh keuntungan. Perlu diketahui bahwa apabila bank selalu mengalami kerugian dalam kegiatan operasinya maka tentu saja lama kelamaan kerugian tersebut akan memakan modalnya. Bank yang dalam kondisi demikian tentu saja tidak dapat dikatakan sehat.Penilaian didasarkan kepada analisis rasio rentabilitas bank.

Analisis rasio rentabilitas bank adalah alat untuk menganalisis atau mengukur tingkat efisiensi usaha dan profitabilitas yang dicapai oleh bank yang bersangkutan. Rasio rentabilitas yang digunakan dalam penelitian ini adalah Return On Asset (ROA). Rasio ini digunakan untuk mengukur kemampuan manajemen bank dalam memperoleh keuntungan (laba) secara keseluruhan. Semakin besar ROA suatu bank, maka semakin besar pula tingkat keuntungan yang dicapai bank tersebut dan semakin baik pula posisi bank tersebut dari segi penggunaan aset (Siamat, 2005).

Youssef Latif, et al (2016) meneliti kinerja antara perbankan syariah dengan perbankan konvensional pada perbankan di Pakistan tahun 2006-2010. Dengan menggunakan analisis trend dan dua belas rasio keuangan (profitabilitas, risiko, likuiditas, dan efesiensi), disimpulkan bahwa kinerja rasio ROA berbeda secara signifikan antara perbankan syariah dan perbankan konvensional dengan kinerja perbankan syariah yang memiliki trend positif yang lebih baik dari tahun ke tahun. Berdasarkan uraian, dapat diajukan hipotesis alternative sebagai berikut.

$\mathrm{H}_{4}$ : Return On Asset (ROA) perbankan syariah dan perbankan konvensional berbeda.

Rasio likuiditas merupakan rasio untuk mengukur kemampuan bank dalam memenuhi kewajiban jangka pendeknya pada saat ditagih. Dengan kata lain, dapat membayar kembali pencairan dana deposannya pada saat ditagih serta dapat mencukupi permintaan kredit yang telah diajukan. Semakin besar rasio ini semakin likuid (Kasmir, 2010). Dalam penelitian ini, rasio likuiditas yang digunakan adalah Loan to Deposit Ratio (LDR).

Loan to deposit ratio adalah rasio untuk mengukur komposisi jumlah kredit yang diberikan dibandingkan dengan jumlah dana dari masyarakat (Kasmir,2010). Rasio ini digunakan untuk mengetahui kemampuan bank dalam membayar kembali kewajiban kepada para nasabah yang telah menanamkan dananya dengan kredit-kredit yang telah diberikan kepada para debiturnya.Semakin tinggi rasionya semakin tinggi tingkat likuiditasnya.

M. Suyanto (2002-2004) membuat perbandingan kinerja Bank Islam (Bank Syariah) dengan Bank Konvensional (Bank Umum atau Bank Komersial) di Indonesia. Pertama, Bank Islam dibandingkan dengan Bank Persero (Bank Pemerintah).Kedua, kinerja Bank Islam dibandingkan dengan Bank Asing.Ketiga, kinerja dibandingkan dengan Bank Konvensional yang terdiri dari 145 bank (Industri Bank). Studi ini menggunakan 9 rasio keuangan untuk kinerja bank. Rasio-rasio ini dikelompokkan dalam empat kategori, yaitu; a. profitability 
(ROA, ROE, IER, NIM); b. liquidity (LDR,FDR); c. risk and solvency (CAR, DTAR, $\mathrm{NPF}$; d. commitment tocommunity (CTA). Analisis peneliti menggunakan ANOVA. Hasil pengujian menunjukkan bahwa rasio LDR bank islam lebih baik dari pada bank asing dan bank umum. Bank Islam lebih berkomitmen terhadap pengembangan masyarakat dibandingkan Bank Persero, Bank Asing dan Bank Umum. Berdasarkan uraian tersebut, dapat diajukan hipotesis alternatif sebagai berikut.

$\mathrm{H}_{5}$ : Loan to Deposit Ratio (LDR) perbankan syariah dan perbankan konvensional berbeda.

\section{METODE PENELITIAN}

Pada penelitian ini,pendekatan yang digunakan adalah pendekatan kuantitatif dengan metode komparatif.Berdasarkan landasan teori dan hipotesis yang dipaparkan, secara umum variabel yang digunakan adalah Capital Adequacy Ratio (CAR), Non Performing Loan (NPL), BOPO, Return On Asset (ROA), dan Loan to Deposit Ratio (LDR).

Penelitian ini merupakan penelitian yang berjenis event study di mana penulis mengamati pengaruh dari suatu fenomena pada saat tertentu. Sedangkan menurut pengungkapan variabel,penelitian ini termasuk ke dalam penelitian komparatif,yaitu penelitian yang mengungkapkan perbedaan keadaan satu dengan keadaan yang lainnya.

Penelitian ini dilakukan dengan mengakses situs-situs yang menyediakan informasi laporan keuangan yaitu situs resmiPT.Bursa Efek Indonesia (www.idx.co.id), Bank Indonesia (www.bi.go.id) dan buku ICMD (Indonesian Capital Market Directory). Objek penelitian ini adalah kinerja perbankan konvensional dan perbankan syariah.

Berdasarkan pokok permasalahan yang dirumuskan maka variabelvariabel yang akan dianalisis dalam penelitian ini adalah sebagai berikut. Variabel bebas adalah variabel yang mempengaruhi atau yang menjadi sebab perubahannya atau timbulnya variabel dependen (Sugiyono, 2007:59). Variabel bebas dalam penelitian ini yaitu: Capital Adequacy Ratio $\left(\mathrm{X}_{1}\right)$, Non Performing Loan (NPL), BOPO, Return On Asset (ROA), dan Loan to Deposit Ratio (LDR). Variabel terikat adalah variabel yang dipengaruhi atau menjadi akibat,karena adanya variabel bebas (Sugiyono, 2007:59). Variabel terikat dalam penelitian ini adalah perbandingan kinerja perbankan syariah dan perbankan konvensional (Y).

Populasi adalah wilayah generalisasi yang terdiri dari obyek atau subyek yang mempunyai kualitas dan karakteristik tertentu yang ditetapkan oleh peneliti untuk dipelajari.Berdasarkan pengertian tersebut diketahui bahwa populasi dalam penelitian ini adalah seluruh perbankan yang terdaftar di BI dan BEI selama periode tahun 2008-2016.Sampel adalah sebagian atau wakil dari populasi yang diteliti. Penelitian ini menggunakan metode nonprobability Sampling, dengan teknik purposive sampling, adalah teknik pengambilan sampel dengan pertimbangan tertentu (Sugiyono, 2010:122). Adapun pertimbangan atau kriteria yang digunakan dalam penelitian ini adalah sebagai berikut, 1) Perbankan yang terdaftar di Bank Indonesia dan menerbitkan laporan keuangan tahunan (annual report) berturut-turut tahun 2008-2016. 2) Perbankan yang 
termasuk sebagai bank devisa. 3) Perbankan konvensional memiliki anak perusahaan bank syariah.

Metode pengumpulan data dalam penelitian ini adalah dengan menggunakan teknik observasi non partisipan, yaitu peneliti tidak terlibat dalam kegiatan sehari-haridari objek yang diamati dan digunakan sebagai sumber data penelitian (Sugiyono, 2007:140). Pengumpulan data dilakukan dengan cara membaca dan mencatat data-data serta informasi yang terkait dengan penelitian ini yang terdapat pada situs Bursa Efek Indonesia (BEI), situs Bank Indonesia, situs Bapepam,dan situs lainnya yang berisi informasi relevan lainnya.

Metode analisis data yang digunakan dalam penelitian ini adalah analisis rasio keuangan (financial ratio analysis). Analisis rasio keuangan berkaitan dengan penilaian kinerja bank dengan menggunakan metode CAMEL yang diproksikan dengan CAR,NPL, BOPO,ROA,dan LDR. Analisis ini didasarkan pada data yang bersifat kuantitatif yaitu data berupa angka-angka yang terdapat pada laporan keuangan bank. Analisis rasio keuangan yang digunakan adalah solvabilitas, rentabilitas, efisiensi, dan likuiditas. Setelah itu, untuk mengetahui kinerja bank secara keseluruhan dilakukan dengan cara menjumlahkan seluruh rasio yang sebelumnya telah diberi bobot nilai tertentu.Kemudian dilakukan interpretasi yang lebih mendalam. Analisis data dilanjutkan dengan membandingkan perolehan rasio dari pendekatan tersebut baik sebelum krisis maupun sesudah krisis kemudian diinpretasikan untuk diperoleh pemahaman yang mendalam.

\section{HASIL DAN PEMBAHASAN}

Berdasarkan pengolahan data dengan menggunakan SPSS, diperoleh statistik deskriptif yang memberikan penjelasan mengenai nilai minimum, nilai maksimum, nilai rata-rata, dan nilai standar deviasi dari masing-masing variabel. Hasil dari statistik deskriptif disajikan pada Tabel 1, berikut.

\section{Tabel 1. Statistik Deskriptif}

\begin{tabular}{lllllll}
\hline Variabel & Jenis & $\mathrm{N}$ & Minimum & Maksimum & Rata-rata & $\begin{array}{l}\text { Standar } \\
\text { Deviasi }\end{array}$ \\
\hline CAR & Bank & 36 & 11,86 & 26,21 & 16,8689 & 3,05843 \\
& $\begin{array}{l}\text { Konvensional } \\
\text { Bank Syariah }\end{array}$ & 36 & 9,40 & 28,80 & 15,1225 & 4,52542 \\
\multirow{2}{*}{ NPL } & Bank & 36 & 0,90 & 4,90 & 2,5414 & 1,03332 \\
& Konvensional & 36 & 1,50 & 7,11 & 3,6728 & 1,47334 \\
& Bank Syariah & & & & & \\
BOPO & Bank & 36 & 45 & 59,93 & 74,0228 & 8,60446 \\
& Konvensional & 36 & 135,10 & 91,25 & 84,6467 & 16,83957 \\
ROA & Bank Syariah & & & & & \\
& Bank & 36 & 1,12 & 5,15 & 3,0158 & 1,10688 \\
& Konvensional & 36 & $-3,60$ & 3,81 & 1,2194 & 1,19569 \\
\multirow{2}{*}{ LDR } & Bank Syariah & & & & & \\
& Bank & 36 & 52,39 & 90,40 & 73,7992 & 11,53134 \\
& Konvensional & 36 & 68,93 & 104,41 & 88,7694 & 8,08752 \\
& Bank Syariah & & & & & \\
\hline
\end{tabular}

Sumber: Data Penelitian,

Berdasarkan Tabel 1, dapat dijelaskan kesimpulan sebagai berikut: 
Variabel CAR memiliki nilai terendah sebesar 11,86 pada Bank Konvensional dan 9,40 pada Bank Syariah sertanilai tertinggi sebesar 26,21 pada Bank Konvensional dan 28,80 pada Bank Syariah dengan rata-rata sebesar 16,8689 pada Bank Konvensional dan 15,1225 pada Bank Syariah. Standar deviasi untuk CAR sebesar 3,05843 pada Bank Konvensional dan 4,52542 pada Bank Syariah, artinya terjadi penyimpangan nilai CAR yang diteliti terhadap nilai ratarata sebesar 3,05843 pada Bank Konvensional dan sebesar 4,52542 pada Bank Syariah.

Variabel NPL memiliki nilai terendah sebesar 0,90 pada Bank Konvensional dan 1,50 pada Bank Syariah sertanilai tertinggi sebesar 4,90pada Bank Konvensional dan 7,11 pada Bank Syariah dengan rata-rata sebesar 2,5414 pada Bank Konvensional dan 3,6728 pada Bank Syariah. Standar deviasi untuk NPL sebesar 1,03332 pada Bank Konvensional dan 1,47334 pada Bank Syariah, artinya terjadi penyimpangan nilai NPL yang diteliti terhadap nilai rata-rata sebesar 1,03332 pada Bank Konvensional dan sebesar 1,47334 pada Bank Syariah.

Variabel BOPO memiliki nilai terendah sebesar 59,93 pada Bank Konvensional dan 45 pada Bank Syariah sertanilai tertinggi sebesar 91,25 pada Bank Konvensional dan 135,10 pada Bank Syariah dengan rata-rata sebesar 74,0228 pada Bank Konvensional dan 84,6467 pada Bank Syariah. Standar deviasi untuk BOPO sebesar 8,60446 pada Bank Konvensional dan 16,83957 pada Bank Syariah, artinya terjadi penyimpangan nilai BOPO yang diteliti terhadap nilai rata-rata sebesar 8,60446 pada Bank Konvensional dan sebesar 16,83957 pada Bank Syariah.

Variabel ROA memiliki nilai terendah sebesar 1,12 pada Bank Konvensional dan -3,60 pada Bank Syariah sertanilai tertinggi sebesar 5,15 pada Bank Konvensional dan 3.81 pada Bank Syariah dengan rata-rata sebesar 3,0158 pada Bank Konvensional dan 1.2194 pada Bank Syariah. Standar deviasi untukROA sebesar 1,10688 pada Bank Konvensional dan 1,19569 pada Bank Syariah, artinya terjadi penyimpangan nilai ROA yang diteliti terhadap nilai rata-rata sebesar 1,10688 pada Bank Konvensional dan sebesar 1,19569 pada Bank Syariah.

Variabel LDR memiliki nilai terendah sebesar 52,39 pada Bank Konvensional dan 68,93 pada Bank Syariah sertanilai tertinggi sebesar 90,40 pada Bank Konvensional dan 104.41 pada Bank Syariah dengan rata-rata sebesar73,7992 pada Bank Konvensional dan 88,7694 pada Bank Syariah. Standar deviasi untukLDR sebesar 11,53134 pada Bank Konvensional dan 8,08752 pada Bank Syariah, artinya terjadi penyimpangan nilai LDR yang diteliti terhadap nilai rata-rata sebesar 11,53134 pada Bank Konvensional dan sebesar 8,08752 pada Bank Syariah.

Uji normalitas bertujuan untuk menguji apakah data sampel yang diteliti berdistribusi normal atau tidak.Pengujian normalitas data dilakukan dengan menggunakan uji Kolmogorof-Smirnov. Jika pada hasil uji Kolmogorof Smirnov menunjukkan nilai signifikasi lebih besar dari 0,05, maka data berdistribusi normal. Sebaliknya, jika nilai signifikasi lebih kecil dari 0,05, maka data tidak berdistribusi normal.

Hasil uji Kolmogorof Smirnov variabel CAR menunjukkan bahwa nilai signifikansi pada Bank Konvensional lebih kecil dari 0,05 $(0,037<0,05)$ dan pada 
Bank Syariah juga lebih kecil dari $0,05(0,000<0,05)$, sehingga dapat disimpulkan bahwa kedua kelompok data tidak berdistribusi normal.

Hasil uji Kolmogorof Smirnov variabel NPL menunjukkan bahwa nilai signifikansi pada Bank Konvensional lebih kecil dari 0,05 $(0,045<0,05)$ dan pada Bank Syariah lebih besar dari 0,05 (0,200>0,05), sehingga dapat disimpulkan bahwa pada Bank Konvensional data tidak berdistribusi normal sedangkan pada Bank Syariah data terdistribusi normal.

Hasil uji Kolmogorof Smirnov variabel BOPO menunjukkan bahwa nilai signifikansi pada Bank Konvensional lebih besar dari 0,05 $(0,200>0,05)$ dan pada Bank Syariah lebih kecil dari 0,05 $(0,000<0,05)$, sehingga dapat disimpulkan bahwa pada Bank Konvensional data terdistribusi nomal sedangkan pada Bank Syariah data tidak terdistribusi normal.

Hasil uji Kolmogorof Smirnov variabel ROA menunjukkan bahwa nilai signifikansi pada Bank Konvensional lebih besar dari 0,05 $(0,200>0,05)$ dan pada Bank Syariah juga lebih besar dari 0,05 $(0,098<0,05)$, sehingga dapat disimpulkan bahwa kedua kelompok data terdistribusi normal.

Hasil uji Kolmogorof Smirnov variabel LDR menunjukkan bahwa nilai signifikansi pada Bank Konvensional lebih besar dari 0,05 $(0,055>0,05)$ dan pada Bank Syariah juga lebih besar dari 0,05 $(0,200>0,05)$, sehingga dapat disimpulkan bahwa kedua kelompok data terdistribusi normal.

Berdasarkan hasil uji normalitas, beberapa variabel pada dua kelompok data tidak terdistribusi normal sehingga dalam pengujian hipotesis peneliti menggunakan uji Mann-Whitney U Test.Pengujian dilakukan dengan melihat nilai signifikansi masing-masing variabel pada output hasil menggunakan SPSS dengan level signifikasi 0,05 ( $\alpha=5 \%$ ). Jika nilai signifikansi lebih kecil dari $\alpha$, maka hipotesis diterima, yang berarti variabel bebas berpengaruh signifikan terhadap variabel terikat.Dengan menggunakan uji Mann-Whitney $U$ Test, diperoleh hasil perbandingan kinerja perbankan syariah dengan perbankan konvensional seperti tampak pada Tabel 2, berikut.

Tabel 2. Perbandingan Kinerja Keuangan Perbankan Syariah dengan PerbankanKonvensional (Mann-Whitney U Test).

\begin{tabular}{llllll}
\hline & CAR & NPL & BOPO & ROA & LDR \\
\hline Mann-Whitney U & 383,000 & 342,500 & 274,000 & 153,000 & 202,000 \\
Wilcoxon W & 1049,000 & 1008,500 & 940,000 & 819,000 & 868,000 \\
Z & $-2,985$ & $-3,441$ & $-4,212$ & $-5,575$ & $-5,023$ \\
Asymp. Sig. (2-tailed) & 0,003 & 0,001 & 0,000 & 0,000 & 0,000 \\
\hline
\end{tabular}

\section{Sumber: Lampiran 4}

Dari Tabel 2, dapat disimpulkan hasil uji hipotesis dari masing-masing variabel sebagai berikut.

Hipotesis pertama dalam penelitian ini adalah berdasarkan CAR, kinerja perbankan syariah dan perbankan konvensional berbeda secara signifikan. Hasil uji menunjukkan bahwa nilai signifikansi variabel CARsebesar 0,003 lebih kecil dari 0,05. Dengan demikian $\mathrm{H}_{1}$ diterima, yang berarti bahwa berdasarkan CAR, kinerja perbankan syariah dan perbankan konvensional berbeda secara signifikan.

Hipotesis kedua dalam penelitian ini adalah berdasarkan NPL, kinerja perbankan syariah dan perbankan konvensional berbeda secara signifikan. Hasil 
uji menunjukkan bahwa nilai signifikansi variabel NPL sebesar 0,001 lebih kecil dari 0,05. Dengan demikian $\mathrm{H}_{1}$ diterima, yang berarti bahwa berdasarkan NPL, kinerja perbankan syariah dan perbankan konvensional berbeda secara signifikan.

Hipotesis ketiga dalam penelitian ini adalah berdasarkan BOPO, kinerja perbankan syariah dan perbankan konvensional berbeda secara signifikan. Hasil uji menunjukkan bahwa nilai signifikansi variabel BOPO sebesar 0,000 lebih kecil dari 0,05. Dengan demikian $\mathrm{H}_{1}$ diterima, yang berarti bahwa berdasarkan BOPO, kinerja perbankan syariah dan perbankan konvensional berbeda secara signifikan.

Hipotesis keempat dalam penelitian ini adalah berdasarkan ROA, kinerja perbankan syariah dan perbankan konvensional berbeda secara signifikan. Hasil uji menunjukkan bahwa nilai signifikansi variabel ROA sebesar 0,000 lebih kecil dari 0,05. Dengan demikian $\mathrm{H}_{1}$ diterima, yang berarti bahwa berdasarkan ROA, kinerja perbankan syariah dan perbankan konvensional berbeda secara signifikan.

Hipotesis kelima dalam penelitian ini adalah berdasarkan LDR, kinerja perbankan syariah dan perbankan konvensional berbeda secara signifikan. Hasil uji menunjukkan bahwa nilai signifikansi variabel LDR sebesar 0,000 lebih kecil dari 0,05. Dengan demikian $\mathrm{H}_{1}$ diterima, yang berarti bahwa berdasarkan LDR, kinerja perbankan syariah dan perbankan konvensional berbeda secara signifikan.

Berdasarkan hasil penelitian yang telah dilakukan pada beberapa bank sebagai representasi dari perbankan syariah dan perbankan konvensional, diperoleh bahwa nilai signifikansi rasio CAR sebesar 0,003 yang lebih kecil dari 0,05. Hal ini berarti bahwa $\mathrm{H}_{1}$ diterima dan $\mathrm{H}_{0}$ ditolak yang menyatakan bahwa berdasarkan rasio CAR ada perbedaan yang signikan terhadap kinerja perbankan syariah dan perbankan konvensional. Nilai mean rasio CAR Bank Syariah sebesar 15,12\% dan mean rasio CAR Bank Konvensional sebesar 16,86\%. Data ini menunjukkan bahwa kemampuan perbankan syariah untuk menanggung risiko dari setiap kredit atau aktiva produktif yang berisiko lebih kecil dibandingkan Bank Konvensional.Hal ini sejalan dengan penelitian Kiki Maharani (2010) yang menyatakan bahwa ada perbedaan kinerja antara perbankan syariah dan perbankan konvensional.Hal ini disebabkan karena modal yang dimiliki oleh perbankan konvensional lebih besar dibandingkan yang dimiliki perbankan syariah karena sejatinya perbankan konvensional sudah beroperasi lebih lama daripada perbankan syariah sehingga memiliki modal yang cukup untuk menanggung risiko dari setiap kredit.

Berdasarkan hasil penelitian yang telah dilakukan pada beberapa bank sebagai representasi dari perbankan syariah dan perbankan konvensional, diperoleh bahwa nilai signifikansi rasio NPL sebesar 0,001 yang lebih kecil dari 0,05. Hal ini berarti bahwa $\mathrm{H}_{1}$ diterima dan $\mathrm{H}_{0}$ ditolak yang menyatakan bahwa berdasarkan rasio NPL ada perbedaan yang signikan terhadap kinerja perbankan syariah dan perbankan konvensional. Nilai mean rasio NPL Bank Syariah sebesar 3,67\% dan mean rasio NPL Bank Konvensional sebesar 2,54 \%. Data ini menunjukkan bahwa persentase kredit bermasalah Bank Syariah lebih besar dibandingkan dengan BankKonvensional.Dalam penelitian Ema Rindawati 
(2007) menyatakan bahwa ada perbedaan kinerja antara perbankan syariah dan perbankan konvensional namun dalam penelitiannya kinerja rasio NPL dan rasio-rasio lainnya pada Bank Syariah lebih baik dari pada Bank Konvensional.Hal ini berbeda dengan hasil penelitian peneliti kali ini, yang menyatakan bahwa rasio NPL Bank Konvensional lebih baik dari Bank Syariah. Hal ini disebabkan oleh kemampuan pengurus bank konvensional yang lebih baik dibandingkan bank syariah untuk mengidentifikasikan, mengukur, memonitor, dan mengendalikan risiko-risiko yang melekat pada seluruh aktivitas bank, jaminan kondisi keuangan yang aman dan sehat, sistem operasional yang efisien dan kepatuhan terhadap hukum dan peraturan yang berlaku.

Berdasarkan hasil penelitian yang telah dilakukan pada beberapa bank sebagai representasi dari perbankan syariah dan perbankan konvensional, diperoleh bahwa nilai signifikansi rasio BOPO sebesar 0,000 yang lebih kecil dari 0,05. Hal ini berarti bahwa $\mathrm{H}_{1}$ diterima dan $\mathrm{H}_{0}$ ditolak yang menyatakan bahwa berdasarkan rasio $\mathrm{BOPO}$ ada perbedaan yang signifikan terhadap kinerjaperbankan syariah dan perbankan konvensional. Nilai mean rasio BOPO Bank Syariah sebesar 84,64\% dan mean rasio BOPO Bank Konvensional sebesar $74,02 \%$. Data ini menunjukkan bahwa tingkat efisiensi Bank Syariah lebih kecil dibandingkan dengan Bank Konvensional dalam menjalankan kegiatan usahanya.Hasil ini sejalan dengan penelitian Widya Wahyu Ningsih (2012) yang menyatakan bahwa berdasarkan rasio BOPO, perbankan konvensional lebih efektif dari perbankan syariah.Hal ini disebabkan karena sistem pengelolaan biaya operasional perbankan konvensional dalam menghasilkan pendapatan operasional lebih baik dibandingkan perbankan syariah yang belum memiliki pengalaman mumpuni dalam pengelolaan finansial perbankan karena masih dalam tahap pengembangan.

Berdasarkan hasil penelitian yang telah dilakukan pada beberapa bank sebagai representasi dari perbankan syariah dan perbankan konvensional, diperoleh bahwa nilai signifikansi rasio ROA sebesar 0,000 yang lebih kecil dari 0,05. Hal ini berarti bahwa $\mathrm{H}_{1}$ diterima dan $\mathrm{H}_{0}$ ditolak yang menyatakan bahwa berdasarkan rasio ROA ada perbedaan yang signifikan terhadap kinerja perbankan syariah dan perbankan konvensional. Nilai mean rasio ROA Bank Syariah sebesar 1,21\% dan mean rasio ROA Bank Konvensional sebesar 3,02 \%. Data ini menunjukkan bahwa tingkat efisiensi dan efektifitas Bank Syariah didalam menghasilkan keuntungan dengan memanfaatkan aktiva yang dimilikinya lebih rendah dibandingkan Bank Konvensional.Hasil ini sejalan dengan penelitian Angraini (2012) yang menyatakan bahwa perbankan konvensional lebih efektif dalam menghasilkan keuntungan dengan memanfaatkan aktiva yang dimilikinya.Dengan kata lain, perbankan konvensional lebih efektif dalam menggunakan asset yang dimilikinya untuk menghasilkan laba.Hal ini terkait juga dengan kualitas manajemen yang mengelola finansial perusahaan yang terbukti dalam penelitian ini bahwa manajemen perbankan konvensional lebih efektif dalam memperoleh laba dibandingkan perbankan syariah. 
Berdasarkan hasil penelitian yang telah dilakukan pada beberapa bank sebagai representasi dari perbankan syariah dan perbankan konvensional, diperoleh bahwa nilai signifikansi rasio LDR sebesar 0,000 yang lebih kecil dari 0,05. Hal ini berarti bahwa $\mathrm{H}_{1}$ diterima dan $\mathrm{H}_{0}$ ditolak yang menyatakan bahwa berdasarkan rasio LDR ada perbedaan yang signifikan terhadap kinerja perbankan syariah dan perbankan konvensional. Nilai mean rasio LDR Bank Syariah sebesar 88,76\% dan mean rasio LDR Bank Konvensional sebesar 73,79 \%. Data ini menunjukkan bahwa tingkat kemampuan Bank Syariah untuk memenuhi kewajiban keuangan yang harus segera dipenuhinya lebih besar dibandingkan dengan Bank Konvensional.Hasil ini sejalan dengan penelitian Indra Prasetyo (2008) yang menyatakan bahwa untuk rasio LDR bank syariah lebih efektif dibandingkan dengan bank konvensional. Hal ini menerangkan bahwa dana yang tersimpan di perbankan syariah terhadap dana yang disalurkan ke masyarakat lebih besar dibandingkan perbankan konvensional. Artinya, perbankan syariah lebih konservatif dalam penyaluran dana sedangkan perbankan konvensional lebih agresif. Namun, perbankan konvensional harus lebih hati-hati kembali dan lebih selektif dalam penyaluran dana bank sehingga likuiditas dapat terjaga dengan baik.

\section{SIMPULAN}

Berdasarkan pengolahan data dan hasil analisis data yang mengacu pada masalah dan tujuan penelitian, maka dapat dirumuskan kesimpulan penelitian sebagai berikut. Hasil ujiMann Whitney $U$ Test menunjukkan rasio CAR, LDR, NPL, BOPO, dan ROA Bank Umum Syariah berbeda secara signifikan dengan Bank Umum Konvensional, sebagaimana yang terlihat sebagai berikut, Nilai CAR Bank Umum Syariah berbeda dengan Bank Umum Konvensional walaupun lebih rendah, akan tetapi rasio CAR Bank Umum Syariah masih berada di atas kriteria kondisi baik yang ditetapkan Bank Indonesia, yaitu melebihi 8\%. Nilai NPL Bank Umum Syariah dengan Bank Umum Konvensional berbeda dan berdasarkan nilai meandapat diketahui bahwa nilai NPL Bank Umum Syariah berada di bawah Bank Umum Konvensional, tetapi rasio NPL Bank Umum Syariah masih berada pada kriteria kondisi baik yang ditetapkan Bank Indonesia yaitu dibawah 5\%. Nilai BOPO Bank Umum Syariah dengan Bank Umum Konvensional berbeda dan berdasarkan nilai mean dapat diketahui bahwa nilai BOPO Bank Umum Syariah berada di bawah Bank Umum Konvensional, tetapi rasio BOPO Bank Umum Syariah masih berada pada kriteria kondisi baik yang ditetapkan Bank Indonesia, yaitu dibawah 92\%. Nilai ROA Bank Umum Syariah dengan Bank Umum Konvensional berbeda dan berdasarkan nilai mean dapat diketahui bahwa nilai ROA Bank Umum Konvensional berada di atas Bank Umum Syariah, tetapi rasio ROA Bank Umum Syariahberada pada kriteria tidak sehat karena berada di bawahketentuan yang ditetapkan Bank Indonesia yaitu lebih dari 1,5\%. Nilai LDR Bank Umum Syariah dengan Bank Umum Konvensional berbeda dan berdasarkan nilai mean dapat diketahui bahwa nilai LDR Bank Umum Syariah berada di atas Bank Umum Konvensional. Rasio LDR Bank Umum konvensional berada di bawah kriteria kondisi baik yang ditetapkan Bank Indonesia, yaitu antara 85-110\%. 
Dari hasil kesimpulan dalam penelitian ini, saran yang dapat diberikan sebagai berikut:Bagi Perbankan Syariah, Secara umum, kinerja perbankan syariah tidak lebih baik jika dibandingkan dengan perbankan konvensional. Oleh karena itu, untuk meningkatkan kualitas rasio-rasio keuangan bank syariah, maka perlu memperhatikan hal-hal sebagai berikut, CAR perbankan syariah dapat ditingkatkan melalui penambahan modal, yakni dengan memperhatikan kebutuhan modal pada setiap ekspansi kredit. Usahakan setiap aset yang berisiko menghasilkan pendapatan sehingga tidak perlu menekan permodalan.ROA dapat ditingkatkan dengan lebih berhati-hati dalam melakukan ekspansi. Usahakan setiap ekspansi senantiasa menghasilkan laba, jangan biarkan aset berkembang tanpa menghasilkan produktifitas.NPL dapat diturunkan dan dijaga supaya tetap di bawah $5 \%$ dengan penyaluran kredit yang lebih hati-hati dan selektif sehingga kredit macet bisa diturunkan lagi. BOPO dapat diturunkan lagi dengan cara mengurangi biaya yang tidak perlu namun efektif untuk menghasilkan laba.Bagi Perbankan Konvensional, Secara umum kinerja Bank Konvensional lebih baik dari pada Bank Syariah namun Bank Konvensional perlu untuk meningkatkan kembali likuiditasnya untuk dapat memenuhi kebutuhan mendesak dari aktiva lancar. Bagi peneliti yang akan datang, Karena penelitian ini hanya menggunakan lima rasio dalam mengukur kinerja perbankan, maka jika ada yang ingin melakukan penelitian sejenis sebaiknya menggunakan lebih banyak rasio untuk mengukur kinerjanya dan memperbanyak sampelnya agar hasil penelitian lebih tergeneralisasi.

\section{REFERENSI}

Antonio, M Syafii. (2001). Bank Syariah bagi Bankir dan Praktisi Keuangan. Jakarta: Gema Insani.

Antonio, Muhammad Syafii. (2001). Bank Syari'ah: Dari Teori ke Praktek. Jakarta: Gema Insani Press bekerja sama dengan Yayasan Tazkia Cendekia.

Ardiyana, Marissa. (2011). Analisis Perbandingan Kinerja Keuangan Bank Syariah dan Bank Konvensional Sebelum, Selama, dan Sesudah Krisis Global Tahun 2008 dengan Menggunakan Metode Camel. http://eprints.undip.ac.id/29852/1/Skripsi012.pdf.Diakses tanggal 22, April, 2012.

Dendawijaya, Lukman. (2003). Manajemen Perbankan. Edisi kedua.Jakarta : Ghalia Indonesia.

Djarwanto dan Pangestu Subagio. (1996). Mengenal Beberapa Uji Statistik dalam Penelitian.Edisi Indonesia. Yogyakarta: Penerbit Liberti.

Hamdan, Umar, dan Andi Wijaya. (2006). "Analisis Komparatif Resiko Keuangan Bank Perkreditan Rakyat (BPR) Konvensional Dan BPR Syariah". 2005. Jurnal Manajemen \& Bisnis Sriwijaya, 4 (7), h: 1-19.

Helfert, Erich A. (1996). Tehnik Analisis Keuangan: Petunjuk praktis untuk mengelola dan mengukur kinerja perusahaan. Edisi kedelapan. Jakarta: Penerbit Erlangga.

Hidayat, Sutan Emir. (2008). Tujuan dan Arah Keuangan Islam, Republika, 4 Agustus 2008.

Horhgen, T. Charles. (2007). Akuntansi di Indonesia. Jakarta: Salemba Empat. IAI. (2004). Standar Akuntansi Keuangan. Jakarat: Salemba Empat. 
Isna, Rahmawati. (2008). Analisis Komparasi Kinerja Keuangan Antara PT. Bank Syariah Mandiri Dan PT. Bank Rakyat Indonesia.Skripsi Sarjana Jurusan Ekonomi Islam pada Stain Surakarta Semi Institute, Yogyakarta.

Indriantoro dan Supomo. (2002). Metodologi Penelitian Bisnis. Yogyakarta: BPFE UGM.

Kasmir, SE., MM. (2000). Analisis Laporan Keuangan. Jakarta: PT. Raja Grafindo Persada.

Kasmir. (2002). Bank dan Lembaga Keuangan Lainny. Edisi Keempat. Jakarta: PT. Grafindo Persada.

Kuncoro, Mudrajad. (2002). Manajemen Perbankan: Teori dan Aplikasi. Yogyakarta: BPFE Yogyakarta.

Lesmana, Yuanita. (2008). Konsistensi Antara Discretionary Accrual dengan Rasio CAMEL dalam Mengukur Tingkat Kesehatan Bank. Jurnal ManajemenUsahawan Indonesia. 37 (5), h: 41-47.

Muhammad. (2001). Teknik Perhitungan Bagi Hasil dan Profit Margin pada Bank Syariah. Yogyakarta: UII Press.

Mulyadi. (2000). Akuntansi Manajemen: Konsep, Manfaat dan Rekayasa. Jakarta: Salemba Empat.

Nasser, Etty M., dan Titik Aryati. (2000). Model Analisis CAMEL Untuk Memprediksi Financial Distress Pada Sektor Perbankan Yang Publik. Jurnal Akuntansi dan Auditing Indonesia (JAAI), 4 (2), h: 111-131.

Payamta, Machfoedz. (1999). Evaluasi Kinerja Perusahaan Perbankan Sebelum dan Sesudah menjadi Perusahaan Publik di Bursa Efek Jakarta (BEJ). Jurnal KELOLA, VIII (20).

Bank Indonesia. (2004). Peraturan Bank Indonesia No. 6/10/PBI/2004 Tentang Sistem Penilaian Kesehatan Bank Umum. Jakarta.

Prasetyo, Indra. (2008). Analisis Kinerja Keuangan bank Syariah dan Bank Konvensional. Jurnal Aplikasi Manajemen, 6 (2), h: 164-168.

Saifudin, Azwar. (2004). Metode Penelitian. Yogyakarta: Pustaka Pelajar.

Siaman, Dahlan. (2005). Manajemen Lembaga Keuangan : Kebijakan Moneter dan Perbankan. Edisi ke-5. Jakarta : Lembaga Penerbit Fakultas Ekonomi Universitas Indonesia.

Siamat, Dahlan. (1993). Manajemen Bank Umum. Jakarta: Intermedia.

Sugiarto, Dergibson, Siagian. (2002). Metode Statistika Untuk Bisnis Dan Ekonomi. Jakarta: Gramedia.

Sugiyono. (2010). Metode Penelitian Bisnis. Bandung: CV Alfabeta.

Sumarti. (2007). Analisis Kinerja Keuangan Pada Bank Syariah Mandiri Di Jakarta. Skripsi Jurusan Manajemen pada Fakultas Ekonomi Universitas Muhamadiyah, Surakarta.

Suseno dan Piter Abdullah. (2003). Sistem dan Kebijakan Perbankan di Indonesia. Pusat Pendidikan dan Studi Ke bank sentralan BI, Jakarta.

Sucipto, (2003). Penilian Kinerja Keuangan. Skripsi Jurusan akuntansi pada Fakultas ekonomi Universitas Sumatera Utara, Sumatara utara.

Suyanto, M. (2004). Perbandingan Kinerja Bank Islam terhadap Bank Persero, Bank Asing dan Bank Umum di Indonesia pada 2000-2004.Skripsi pada STMIK AMIKOM, Yogyakarta. 
Taswan. (2000). Akuntansi Perbankan.Yogyakarta: Penerbit, Unit Penerbitan dan Percetakan Akademi Manajemen Perusahaan YKPN.

Warkum, Sumitro. (2002). Asas-Asas Perbankan Islam dan Lembaga-Lembaga Terkait BMI dan Takaful. Jakarta : PT Raja Grafindo Persada.

Susilo, Sri Sigit Triandaru, dan A. Totok Budi Santoso. (2005). Bank dan Lembaga Keuangan Lain. Jakarta: Salemba Empat.

Weston J. Fred dan Eugene F. Brigham.(Alfonsus Sirait, penerjemah). (1993). Dasar-dasar Manajemen Keuangan, Jilid 2. Edisi Kesembilan. Jakarta: Erlangga.

Wisdagdo, Ari Kuncara, dan Siti Rochmah Ika. (2008). The Interset Prohabition and Financial Performance of Islamic Banks: Indonesia Evidence. Jurnal International Businees Research, 1 (3).

Wirawan, Nata. (2002). Statistik 2 untuk Ekonomi dan Bisnis. Edisi Kedua. Denpasar: Keararas Mas. 